Joke M. M. den Haan ${ }^{1}$,

Ronald E. Bontrop ${ }^{2}$,

Jos Pool',

Nicholas Sherman ${ }^{3}$,

Els Blokland',

Victor H. Engelhard ${ }^{4}$,

Donald F. Hunt ${ }^{5}$ and

Els Goulmy ${ }^{1}$

${ }^{1}$ Department of

Immunohaematology and

Bloodbank, Leiden University

Hospital, Leiden, The Netherlands

Department of Immunobiology,

Biomedical Primate Research

Centre, Rijswijk, The Netherlands

Department of Chemistry,

University of Virginia,

Charlottesville, USA

+ Department of Microbiology and

Berrne Carter Center for

Immunology Research, University

of Virginia, Charlottesville, USA

Departments of Chemistiy and

Pathology, Unıversity of Virgını,

Charlottesville, USA

\section{Conservation of minor histocompatibility antigens between human and non-human primates}

It is well accepted that minor histocompatibility antigens (mHag) can function as transplantation barriers between HLA-matched individuals Little is known about the molecular nature and evolutionary conservation of mHag It is only very recently that the furst human $\mathrm{mHag}$ were identified The HLA-A2 1 restricted $\mathrm{mHag} \mathrm{HA}-2$ and the HLA-B7-restricted mHag $\mathrm{H}-\mathrm{Y}$ appeared to be peptides derived from polymorphic self proteins Here we show that the HLAA2 1-restricted mHag HA-1, HA-2, and the H-Y peptides are conserved between man, chimpanzees and rhesus macaques Human cytotoxic $T$ cell clones specific for the HLA-A2 1-restricted mHag HA-1, HA-2, and H-Y recognized HLA-A2 1 gene-transfected chimpanzee and rhesus macaque cells Highpressure liquid chromatography fractionation of HLA-A2 1-bound peptides isolated from the HLA-A2 1-transfected chimpanzee cells revealed that the chimpanzee HA-1 and HA-2 co-eluted with the human HA-1 and HA-2 Subsequent amıno acid sequencing showed that the chimpanzee HA-2 peptide is identical to the human HA-2 peptide Our functional and brochemical results demonstrate that mHag peptides are conserved for over 35 million years

\section{Introduction}

Disparity for minor histocompatrbility antigens (mHag) between HLA-identical individuals can lead to graftversus-host disease (GVHD) after bone marrow trans plantation [1] MHag-specific HLA-1estricted T ccll clones can be generated of PBMC from patients suffering trom GVHD [2 3] Using $\mathrm{T}$ cell clones specific for $\mathrm{mHag} \mathrm{HA}-1$ HA-2, HA-4, and HA-5, we showed that these non-sex linked $\mathrm{mHag}$ segiegate as Mendelian tiaits and indepen dently trom each other Edch can be considered as the pioduct of a gene with two alleles [4] Population genetic studies revealed that $\mathrm{HA} 1$ and $\mathrm{HA}-2$ appedred frequently $(69 \%$ and $95 \%)$, whereas HA-4 and HA-5 occurred with lower trequencies (16\% and $8 \%$ ) in the healthy population [5] Recently, the first two human mHag have been identified by amino acid sequencing of the HLA-bound peptides that were recognized by the $m$ Hag specific $T$ cell clones The non-sex-linked HLA-A2 1-restricted mHag HA-2 most probably originates from a member of the class I myosin proten family [6] and the male-specific HLA-B7 restricted mHag $H Y$ is derived from the $Y$ chromosome-encoded SMCY (selected mouse cDNA on the Y) protein [7] The SMCY gene was shown to be con

[l 16082$]$

Recuved August 81996 accepted August 261996

Correspondence: Ioke M M den Hadn, Depatment of Immuno hacmatology and Bloodbank, Leiden University Hospital, Albi nusitreef 22333 ZA Leiden The Netherlands

$\mathrm{Fdx}+31715216751$ emal hadn1@rulged leidenunvnl

Abbrevation: mHag: Minor histocompatibility antigen

Key words: Minor histocompatibility antıgen / Evolution / Cyto tovic $\Gamma$ cell / Graft-versus host disedse served in evolution [8] However until now no information existed on the evolutionary conservation of human non-sex linked mHag In the present study wo investıg dted whether the human non-sex-linked HLA-A2 1 lestricted mHag HA-1, HA-2, and HA-4 and the malespecific HLA-A2 1-restricted $m$ Hag $H$ Y are evolutionarv conserved For this functional studies biochemical puri fication and amino acid sequence analyses were per formed We transtected chmpanzee and rhesus macaque $B$ cell lines with the HLA-A2 1 restinction molecule and used these cells as target cells for recognition by the HLAA2 1 trstricted mHag-specific CTL clones Subsequently the mHag HA-I and HA-2 peptide were eluted trom the tiansfected HLA-A2 1 chimpanzee cells and showed simila1 HPLC elution patterns when compared with human HA 1 and HA-2 peptides Sequence analysis of chimpanLee HA-2 tevealed an amino acid sequence identical to the human HA-2

\section{Materials and methods}

\subsection{Transfection and cell culture}

Chimpanzee $B$ cell lines were generated from six unrelated chimpanzees derived from the Biomedical Primate Research Centre colony Theo (chimpanzee, 1, $\delta$ ), Pearl (chimpanıec 2, $q$ ), Debbie (chimpanzee 3, $q$ ), Brigitte (chimpanzee 4, $\$$ ), Sherry (chumpanzee 5, $q$ ), Japie (chmpanzee $6, \hat{0}$ ) Two thesus macaque B coll lines were generated from 2849 (rhesus macaque 1, $q$ ) and IWM (1 hesus macaque 2, ${ }^{\star}$ ), both derived from the Biomedical Primate Research Centre colony The cells were maintaned in RPMI 1640 medium containing $10 \%$ tetal calf serum and $3 \mathrm{mM}$ I-glutamine Rhesus macaque cell lines were cultured in the presence of $06 \mu \mathrm{g} / \mathrm{ml} 3^{\prime}$-azido-3'- 
deoxythymidine Cells were transfected with pHEBO A2 1 by electroporation using a Bio-Rad Gene Pulser Cells were routinely shocked at $960 \mu \mathrm{F}, 210 \mathrm{~V}$ in the presence of $625 \mu \mathrm{g} / \mathrm{ml}$ uncut plasmid DNA Cuvettes of $04 \mathrm{~cm}$ were used, with about $12 \times 10^{6}$ cells in $08 \mathrm{ml}$ phosphatc-buffered salıne Transfected cell lines were maintained in the presence of $125-250 \mu \mathrm{g} / \mathrm{ml}$ hygromycin [9] The HLAA2 1-allospecific CTL clones $3 E 7$ and 3E5, the HLAA2 1-restricted HA-1-specitic CTL clone 3HA15, the HLA-A2 1-restricted HA-2-specific CTL clone 5H13, the HLA-A2 1-restricted HA-4-specific CTL clones 5 G30 and 5Gy8, and the HLA-A2 1-restricted H-Y-specific CTL clone 1R35 were cultured by weekly stimulation with irradiated dllogeneic PBMC and B-lymphoblastord cell line (BLCL) cells in RPMI 1640 medium containing $15 \%$ human serum, $3 \mathrm{mM}$ L-glumtaine, $1 \%$ leukoagglutinin A and $20 \mathrm{U} / \mathrm{ml}$ recombinant IL-2 [5]

\section{$2.2{ }^{51} \mathrm{Cr}$-release assay}

${ }^{\prime} \mathrm{Cr}$-labeled target cells (5000) were incubated together with different numbers of HLA-A2 1-allospecific and mHag-specific CTL clones in $200 \mu \mathrm{l}{ }^{{ }^{*}} \mathrm{Cr}$ ielease was determined after $4 \mathrm{~h}$ dt $37^{\circ} \mathrm{C}$ The percent specific lysis was calculated as follows percent specific lysis $=\lfloor$ (exper1mental release - spontaneous release)/(maxımal release - spontaneous release] $\times 100$ Spontaneous release and the maximal release were the ${ }^{51} \mathrm{Cr}$ release of the target cells in culture medium alone and in culture medium containing $1 \%$ Triton $\mathrm{X}-100$, respectively

\subsection{Peptide purification}

Peptides were eluted out of purffied HLA-A2 1 molecules as described $[6,10]$ Briefly, HLA-A2 1 molecules were purified from $205 \times 10^{10}$ transfected chimpanzee cells by affinity chromatography with BB7 2-coupled CNBr activated Sepharose 4B beads (Pharmacia LKB, Uppsald Sweden) Peptides were eluted from the HLA-A2 1 molecules by acid treatment and separated from the HLA A2 1 heavy chain and $\beta 2$-microglobuln by filtration over a 10 kDa-cutoff Centricon (Amicon, Lexington, MA) filter Peptides were tractionated using reverse-phase micro HPLC (Smart System, Pharmacia) Buffer A was $01 \%$ trifluoroacetic acid (TFA), bufter $B$ was $01 \%$ TFA in acetonitrile The gradıent consisted of $100 \%$ buffer $\mathrm{A}(0)$
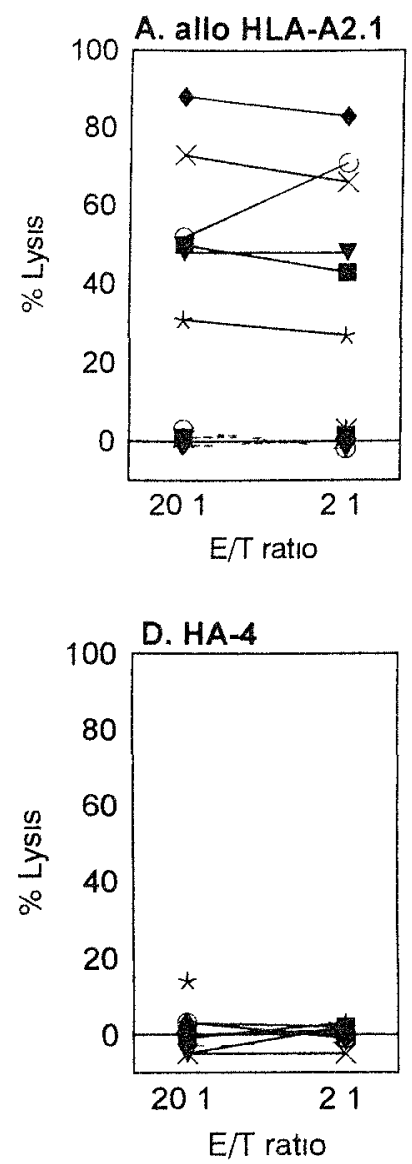
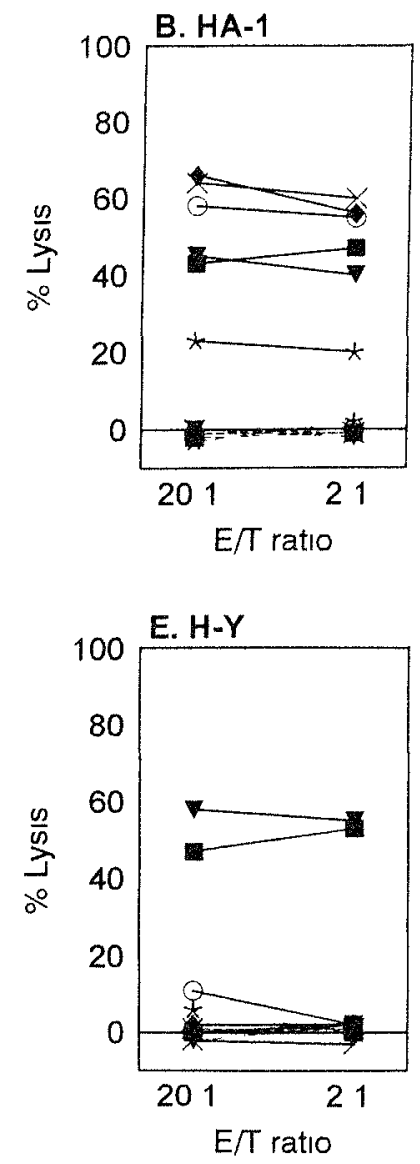
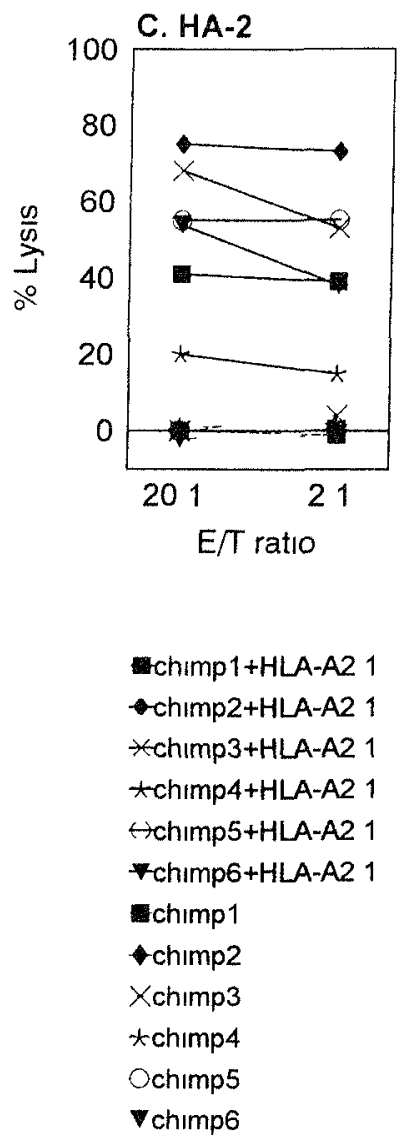

Figure 1 HLA-A2 1-transfected chimpanzee cell lines are lysed by HLA-A2 1-allospecific and by HLA-A2 1-restricted HA 1, IIA 2 and H-Y-specific CTL clones (A) Lysis by the HLA A2 1-dllospecific CTL clone, (B) lysis by the HLA-A2 1-restricted HA-1-specific C TL clone, (C) lysis by the HLA-A2 1 restricted HA-2 specific CTL clone, (D) lysis by the HLA-A2 1-restricted HA-4-specific CTL clone, and (E) lysis by the HLA-A2 1 restricted H-Y-specific CTL clone Solid lines represent the HLA-A2 1 transtected cell lines, and dotted lines represent the nontranstected cell lines All E/ $\Gamma$ ratios tested were 201 and 21 except for chimpancee 6 For both the HLA A.2 1 transfected and the nontransfected chimpanzee 6 ccll line, E/T ratios of 131 and 131 were used for the HLA A2 1 allospecific CTL, E/T ratios of 51 and 051 werc used for the HA-4-specific CTL and E/T ratios of 111 and 111 were used tor the HLA A2 1 rcstricted H-Y CTL 
$20 \mathrm{~min}$ ), 0 to $12 \%$ buffer B (20 to $25 \mathrm{~mm}$ ), and 12 to $50 \%$ buffer B (25 to $80 \mathrm{~min})$ at a flow rate of $100 \mu \mathrm{l} / \mathrm{min}$. Fractions of $100 \mu \mathrm{l}$ were collected. In the ${ }^{51} \mathrm{Cr}$-release assay, $2.5 \mu \mathrm{l}$ of each fraction was diluted in $25 \mu \mathrm{l}$ HBSS butfered with $50 \mathrm{mM}$ Hepes. ${ }^{51} \mathrm{Cr}$-labeled T2 cells (2500) were incubated with the fractions in $50 \mu \mathrm{l}$ for $30 \mathrm{~min}$ at $37^{\circ} \mathrm{C}$. HA-2-specific $T$ cells were added for an $E / T$ ratio of $17: 1$ in final volume of $150 \mu \mathrm{l}$ for $4 \mathrm{~h}$ at $37^{\circ} \mathrm{C}$.

\subsection{Mass spectrometry}

Collision-activated dissociation spectra were recorded on a triple-quadrupole mass spectrometer (Finnigan-MAT, San Jose, CA) operating with a two mass-unit window in quadrupole 1 .

\section{Results}

\subsection{Recognition of HLA-A2.1-transfected chimpanzee and rhesus macaque $B$ cell lines by human $m H a g-$ specific CTL clones}

Six unrelated chimpanzee (Pan troglodytes) and two unrelated rhesus macaque (Macaca mulatta) B cell lines were transfected with the HLA-A2.1 gene and analyzed with HLA-A2.1-restricted mHag-specific CTL clones in a ${ }^{51} \mathrm{Cr}$ release assay (Figs. 1,2). All transfected cell lines were recognized by the HLA-A2.1-allospecific CTL clone (Figs. 1A, 2A). Differences in lysis by the HLA-A2.1-allospecific CTL clone was correlated with differences in HLA-A2.1 expression as determined by FACS analysis (data not shown). The HA-1- and HA-2-specific CTL clones lysed all six chimpanzee and two rhesus macaque cell lines, whereas no HA-4 reactivity could be detected (Figs. 1B-D; 2B-D). All HLA-A2.1-transfected male chimpanzee and rhesus macaque cell lines were recognized by the HLA-A2.1-restricted $\mathrm{H}$-Y-specific CTL clone (Figs. 1E, 2E). These results demonstrate that the HA-1, $\mathrm{HA}-2$, and $\mathrm{H}-\mathrm{Y}$ T cell epitopes are functionally expressed on these cells.

\subsection{Chimpanzee HA-1 and HA-2 peptides have similar HPLC retention times as human HA-1 and HA-2}

To test the assumption that the endogenously processed mHag HA-1 and HA-2 peptides in non-human primates are tdentical to the human HA-1 and HA-2, HLA-A2.1bound peptides were isolated from an HLA-A2 Itransfected chimpanzee cell line as described $[6,10]$. After
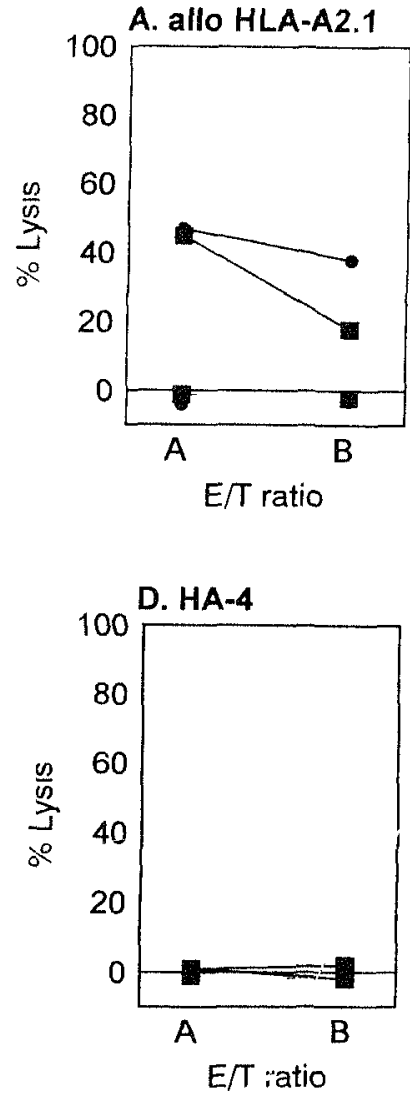

B. HA-1
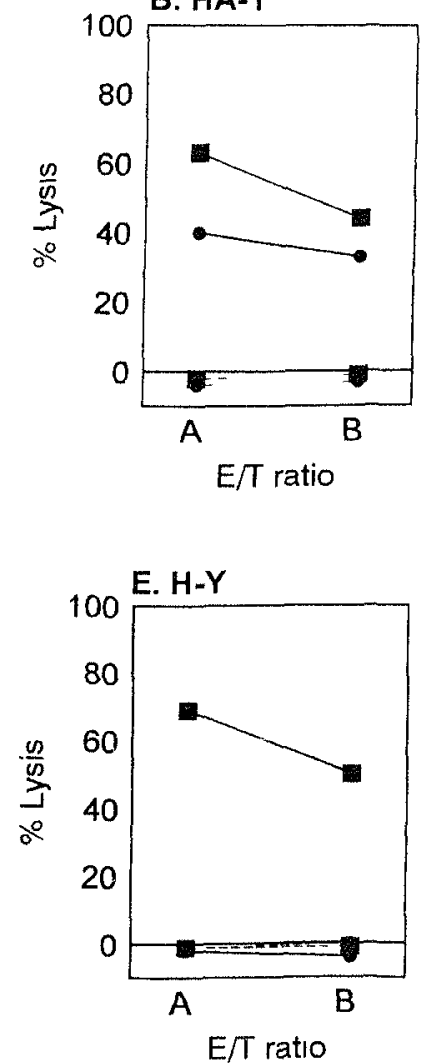

C. $\mathrm{HA}-2$

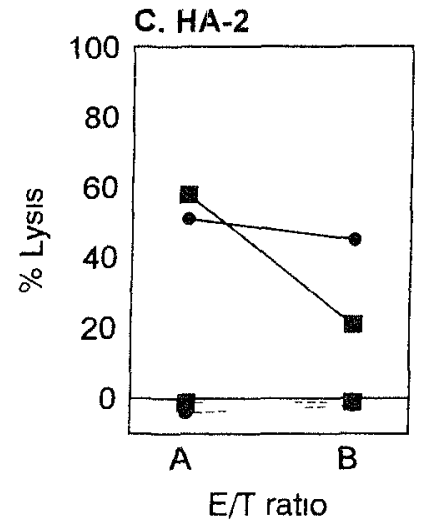

Figure 2 HLA-A2 1-transfected rhesus macaque cell lines are lysed by HLA-A2.1-allospecific and by HLA-A2.1-restricted HA-1, HA2, and H-Y-specific CTL clones (A) Lysis by the HLA-A2 1-allospecific CTL clone, (B) lysis by the HLA-A2.1-restricted HA-1specific CTL clone, (C) lysis by the HLA-A2 1-restricted HA-2-specific CTL clone, (D) lysis by the HLA-A2 1-restricted HA-4-specific CTL clone, and (E) lysis by the HLA-A2 1-restricted H-Y-specific CTL clone Solid lines represent the HLA-A2.1-transfected cell lines and dotted lines represent the nontransfected cell lines $\mathrm{E} / \mathrm{T}$ ratios (A) in (B) werc 10:1 and $1: 1$ tor the transfected as well as the nontranstected rhesus macaque 1 cell line tor all CTL clones except for the HA-1-specific CTL clone, where E/T ratios of $30: 1$ and $3 \cdot 1$ were used. For both the transfected as the nontransfected rhesus macaque 2 cell line, E/T ratio A was between $7 \quad 1$ and 20.1 and ratio $B$ was between 071 and 21 for the different CTL clones 

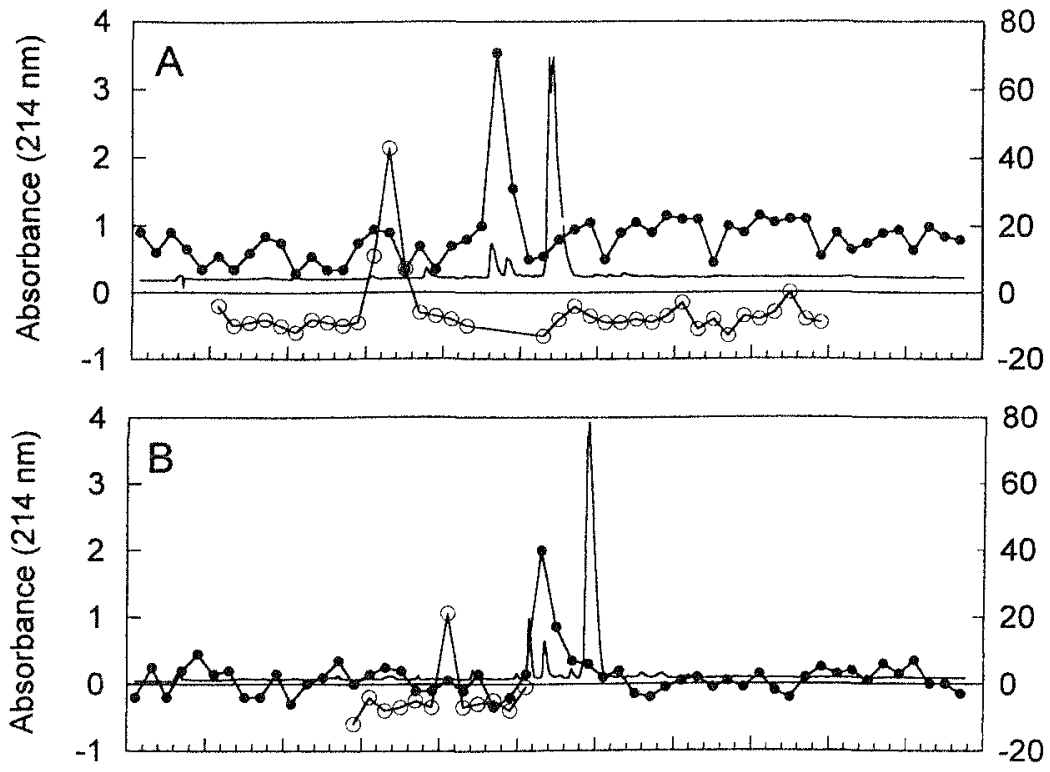

Figure 3 (A) Activity of HPLC fractions of HLA A2 1 eluted chimpanzec peptides in a ${ }^{5} \mathrm{Cr}$ release assay using $\mathrm{HA} 1$ and $\mathrm{HA} 2$ ¿ specific CTL clones as effector cells compared with the HPLC elution profile of a reference peptide (B) Activity of HPLC fractions of HLA A2 1 eluted human peptides in a $\mathrm{Cr}$ release assay using $\mathrm{HA} 1$ and $\mathrm{HA} 2$ specific CTL clones as effector cells and compared with the HPLC elution profile of a refcrence pep tide For both HA-1 (open circles) and HA 2 (closed circles), one peak of activity was found in the chimpanzee and the human HLA A2 1 eluted peptides Both the chimpanzee and human HA 2 active fractions were found at the same position when compared with the elution profile of the reference peptide (solid line) The human and chimpanzee HA 1 detive fractions eluted six and seven fractions earher when com pared with the HA 2 active fractions This shitt of one fraction of HA 1 is within the normil range of variation between HPLC runs
HPLC fractionation, the chimpanzee peptide fractions were assayed with the mHag HA-1 and HA 2 specific CTL clones For both HA-1 and HA-2 that were eluted from the transfected chimpanzee cells, one peak of activity was found (Fig 3A) which was also observed for human HLA A2 1 eluted peptides ( $F_{1} g$ 3B) When the positions of the HA 1 and HA-2 dctive fractions were compared to the elu tion profile of a reference peptide that was run immediately before the eluted peptides, both the chimpanzee HA-1 and HA-2 active fractions eluted approximately at the same position as the human HA 1 and HA 2 active fractions This suggests that the chimpanzee HA 1 and HA-2 peptides have similar biochemical properties as the human HA-1 and HA-2 peptides

\subsection{The chimpanzee and human mHag HA-2 peptide sequence is identical}

Recently, we identified the human mHag HA 2 as YIGEVLVSV with a mass-to-charge ratio of $\mathrm{m} / \mathrm{z} 978$ [6] Collision-activated dissociation (CAD) analysis by tandem mass spectrometry of $\mathrm{m} / \mathrm{z} 978$ in the chimpanzee HA-2 positive fraction revealed the sequence YXGEVXVSV (Fig 4A), which is identical to the human HA-2 amino acid sequence (Fig 4B) Since the mass spectrometer we used cannot differentiate between Leu and Ile (represented by $X)$, it remains to be established whether positions 2 and 6 encode Leu or Ile, which is also true for the human mHag HA-2 [6]

\section{Discussion}

Humans, chimpanzees and rhesus macdques share a common ancestor that lived 35 million years ago [11] The divergence between man and chimpanzees took place around 5 million years ago [12] The functional recognition of the HLA-A2 1 transfected chimpanzee and rhesus macaque cells by the H--Y, HA 1 and HA-2-specific CTL and the biochemical peptide characterization of the non human primate mHag clearly demonstrate that human
mHag peptides are conserved for at least 35 millon icals of primate evolution Thus the $\mathrm{mHdg}$ protens leading to these mHag peptides are of functiond importance Morc over the mHag peptide identity shows that the proccssing and presentation machinery in respect to $\mathrm{mHag}$ is con seived as well This underlines earlicr suggestions that the processing and presentation machinery may be conscrved between species in general It has been shown that $\mathrm{H} 2 \mathrm{~K}$ transfected human cells could present allopeptides to mouse $\mathrm{H} 2 \mathrm{~K}^{\mathrm{b}}$ restricted CTL [13] Furthermore lysis was observed of $\mathrm{H}-2 \mathrm{~K} /$ vaccinia virus-transfected rat Sviran hamster, monkey and human cells by mouse $\mathrm{H}_{2} \mathrm{~K}^{1}$ restricted vaccinia specific CTL [14]

Information on conservation of mHag is scarce except for the mHag H-Y Recently, both a human HLA B7restricted $\mathrm{H}-\mathrm{Y}$ antigen and a mouse $\mathrm{K}^{\mathrm{k}}$-restricted $\mathrm{H}-\mathrm{Y}$ antigen were shown to be derived from the $Y$ chromosome encoded SMCY protein $[7,15]$ This protein is evolutio narily conserved and expressed in both humans and mice although the $\mathrm{H}-\mathrm{Y}$ T cell epitopes are not Conservation of an HLA-B27-restricted $\mathrm{H}-\mathrm{Y}$ antigen has been described in HLA-B27-transgenic mice and rats, however, human cells were not recognized by the rat $\mathrm{H}-\mathrm{Y}$-specific HLA B27 restricted CTL [16] Although it remains to be established whether other H-Y mHag, like the HLA-A2 1 restricted $\mathrm{H}-\mathrm{Y}$ T cell epitope, are also encoded by the SMCY gene, we show here that the HLA-A2 1-restricted $\mathrm{H}-\mathrm{Y}$ peptide is also conserved in evolution

The phenotype frequencres of $\mathrm{mHag} \mathrm{HA}-1, \mathrm{HA} 2$, and HA-4 in the HLA-A2 $1^{+}$Caucasian population are $69 \%$ $95 \%$, and $16 \%$, respectively [5] All the chimpan 5 ee and rhesus macaque HLA-A2 1-transfected cell lines analyzed in this study expressed HA-1 and HA-2, whereas none expressed HA 4 These results suggest that different phe notype frequencies may exist for the mHag in non-human primates Alternatively, the polymorphisms of the HA 1, HA 2, and the HA 4 loci may have a risen after the diver gence between chimpanzee and man However, the num ber of chimpanzee and rhesus macaque cell lines andlyzed in this study is too low to draw any conclusions 

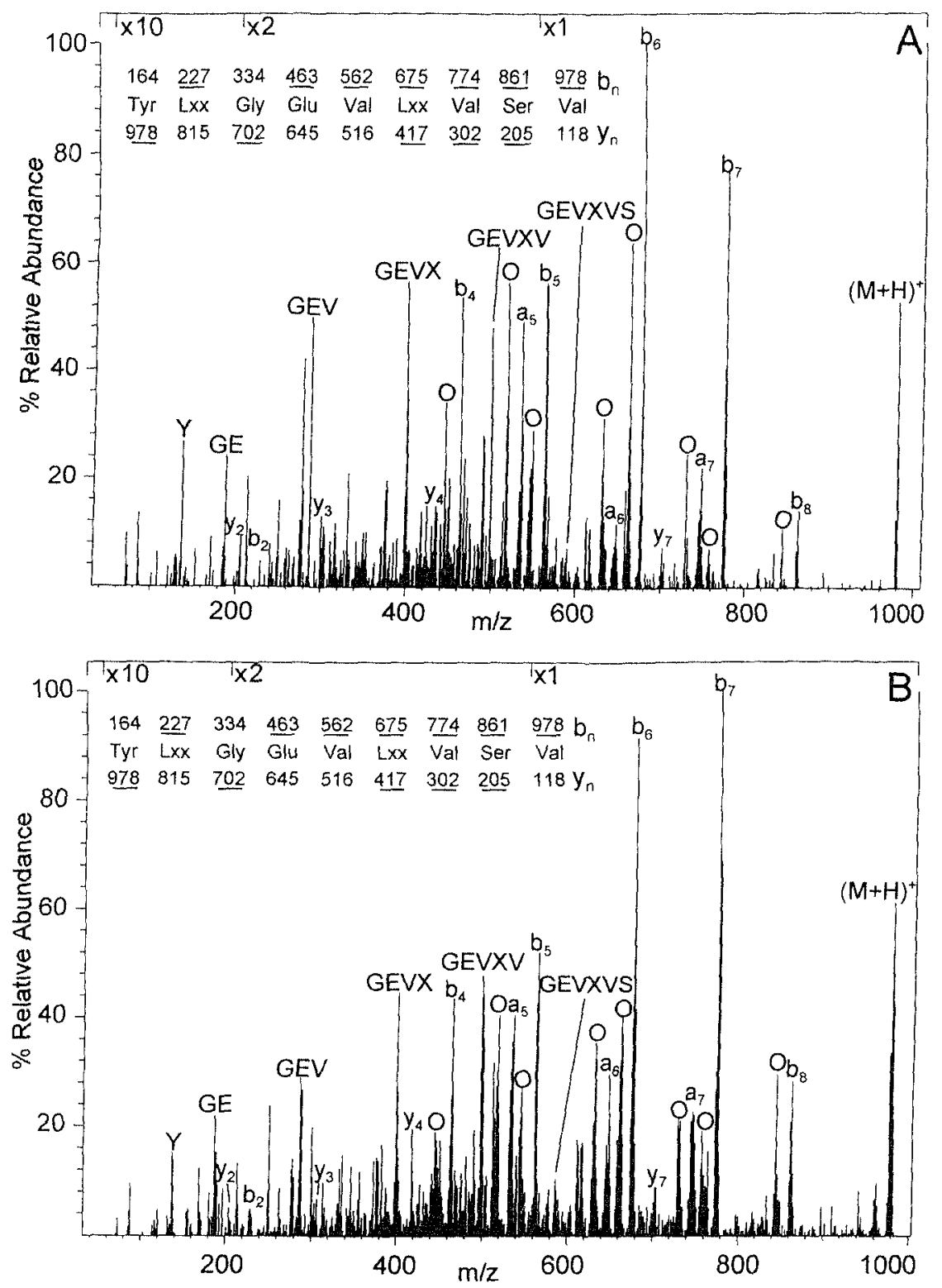

Figure 4 Collision activated dissociation mass spectrum of mHag HA $2(\mathrm{M}+\mathrm{H})^{+}$lons with $\mathrm{m} / \mathrm{z} 978$ The predicted mass for fragment ions of type b and $y$ are shown, respectively above and below the deduced ammo acid sequence Ions observed in the spectrum are underlined Lxx epresents lle or Leu which have identical masses and cannot be differentiated in this mass spectiometer (A) Spectium of peptide YXGEVXVSV obtained from chimpanzee cells (B) Spectium of peptide YXGEVXVSV obtamed from human cells

This study is the first demonstration of evolutionary conselvation of non-sex-linked human mHag On the one hand, the identity of human and chimpanzee mHag may have implications for xenotransplantation Xenotransplantation of non-human primate tissue can lead to $T$ cell responses to mHag peptides presented via the indirect pathway On the other hand, our results show the possibility to use non-human primates as a model to study bone marrow transplantation-related , eactivities such as GVHD and graft-versus-leukemia reactions

We thank $\operatorname{Dr} N$ Holmes for the zift of the HLA-A2 1 pHEBO vector We thank Dr Ottenhoff and Dr Kontng for critical reading the manuscript The work was supported by grants from the I A Cohen Institute for Radiopathology and Radiation Protection ( $E G$ ), the Dutch organization for Sctentific Research (NWO 901 09201 to $J M M d H$ ) and the US Public Health Service (A120963 to $V H E$ and AI33993 to D FH)

\section{References}

1 Goulmy, E, Schipper, R Pool, J, Blokland E Falken burg, J H F, Vossen, J, Gratwohl, A, Vogelsang, G B , van Houwelingen, $\mathrm{H} C$ and van Rood, J J , $N$ Engl $J$ Med 1996334281

2 Goulmy, E In Morris, P J and Tilney, N L (Eds) Transplantation Revtews, W B Saunders Company, Phıladelphı 1988229

3 Goulmy, E, Curr Opin Immunol 1996875

4 Schreuder, G M T, Pool, J, Blokland, E, van Els, C, Bak ker, A, van Rood, I J and Goulmy, E, Immunogenettcs 19933898

5 van Els, C A C M, D'Amaro, J, Pool, J, Blokland E, Bakker, A, van Elsen, $\mathrm{P} J$, van Rood, $\mathrm{J} J$ and Goulmy, E Immunogenetics $1992 \quad 35 \quad 161$

6 den Haan, J M M, Sherman, N E, Blokland, E, Huczho E Konnng, F, Driffhout, J W, Skıpper, J, Shabanou ttz, J, Hunt, D F, Engelhard, V H and Goulmy E, Science 1995 $268 \quad 1476$

7 Wang W, Meadows L R, den Hadn, J M M Sherman, $\mathrm{N} E$, Chen, $Y$, Blokland, E , Shabanowitz, J, Agulnık, A I Hendrickson, $R$ C Brshop $C$ E, Hunt D F 
Goulmy E and Engelhard, V H, Scence 19952691588

8 Agulnik I A, Mitchell, M J, Lerner, J L Woods D R and Bishop, C E, Hum Mol Genetles 19943873

9 Goulmy, E , Pool, J , Blokland, E, and Geraghty, D , Immu nogenetus 199134270

10 de Bueger M, Verreck, F, Blokland, E, Drufhout, J W, Amons, R, Koning, F and Goulmy, E, Eur I Immunol 199323614

11 Martin, R D , Nature 1993363223

12 Miyamoto M M, Koop, B F, Shightom, I L, Goodman, $M$ and Tennant, M R, Proc Natl Acad Scl USA 198885 7627
13 Ialk, $\mathrm{K}$ Rot/schkc, $\mathrm{O}$ and Rammensee, $\mathrm{H} \mathrm{G}$, IuI I Intmunol 1992221323

14 Lobigs, M and Mullbacher, A, Proc Natl Acad ScI USA 1993902676

15 Scott, D M Ehrmann I E, Ellis P S, Bishop, C E Agulnık, A I , Simpson, E and Mitchell, M J , Nature 1995 376695

16 Simmons, W A, Taurog I D, Hammer, R E and Breban $\mathrm{M}$, Immunogenencs $1993 \quad 38351$ 